\title{
Revision of the genus Afrogyrodactylus Paperna, 1968 (Monogenea: Gyrodactylidae) with description of two new species from geographically distant localities
}

\author{
Iva Přikrylová ${ }^{1,2}$ and Wilmien J. Luus-Powell ${ }^{2}$ \\ ${ }^{1}$ Department of Botany and Zoology, Faculty of Science, Masaryk University, Brno, Czech Republic; \\ ${ }^{2}$ Department of Biodiversity, School of Molecular and Life Sciences, University of Limpopo, Sovenga, South Africa
}

\begin{abstract}
This study revises the originally monotypic genus Afrogyrodactylus Paperna, 1968 (Monogenea), the species of which infect alestid fish (Characiformes) in Africa, and includes new records of these parasites from three geographically distant countries, Senegal, Sudan and South Africa. Morphology of opisthaptoral hooks and bars and nuclear ribosomal DNA data revealed three Afrogyrodactylus species. Afrogyrodactylus girgifae sp. $\mathrm{n}$. is described from the fins of the Sudanese nurse tetra, Brycinus nurse (Rüppell), and $A$. kingi sp. n. presents from the gill arches of the South African sharptooth tetra, Micralestes acutidens (Peters), whereas a previously undescribed Afrogyrodactylus sp. occurred on the fins of $B$. nurse from Senegal. All three species differ conspicuously from the only one known species of this genus, A. characinis Paperna, 1968, by the dimensions of their haptoral hard parts. Detailed morphological and molecular descriptions and comparisons are presented.
\end{abstract}

Keywords: taxonomy, morphology, new species, ITS rDNA, Alestidae, South Africa, Sudan, Senegal, Etiopian region

Flatworms of the family Gyrodactylidae Cobbold, 1864 (Platyhelminthes: Monogenea) are ectoparasites with a worldwide distribution in both marine and freshwater environments. To date, species from five genera have been described from African freshwater fish. These are the cosmopolitan Gyrodactylus von Nordmann, 1832, and Afrogyrodactylus Paperna, 1968, Diplogyrodactylus Přikrylová, Matějusová, Musilová, Gelnar et Harris, 2009, Macrogyrodactylus Malmberg, 1957 and Mormyrogyrodactylus Luus-Powell, Mashego et Khalil, 2003, which are endemic to the continent. Another genus, Gyrdicotylus Vercammen-Grandjean, 1960, has been reported from a non-fish host, the African clawed toad Xenopus laevis Daudin (see Vercammen-Grandjean, 1960).

Tetras of the family Alestidae Cockerell are a group of characiform fish exclusive to Africa that comprises of 18 families and 110 species (Nelson 2006). Alestid fish in Africa are parasitised by a number of monogeneans, including both monopisthocotyleans and polypisthocotyleans. Amongs the monopisthocotyleans, only two gyrodactylids (Afrogyrodactylus characinis Paperna, 1968 and Gyrodactylus microalestis Paperna, 1968) have been found on these fishes, which are also infected by species of numerous dactylogyrid genera including Anulotrema von Nordmann, 1832, Characidotrema Paperna et Thurston, 1969 and Afrocleidodiscus Paperna, 1969 (see Thurston 1970, Ergens 1973, Paperna 1973, Molnar and Mossalam
1985, Birgi 1988). Diplozoon gahense Thomas, 1957 is the only polypisthocotylean recorded from these fish and was found on Alestes macrolepidotus Valenciennes and Alestes baremoze (Joannis) (see Thomas 1957, Paperna 1969, respectively).

The first and only species of the genus Afrogyrodactylus was originally described from Micralestes sp. sampled in Lake Volta (Paperna 1968), but was later synonymised with Gyrodactylus (see Paperna 1979). However, Bakke et al. (2007) suggested that Afrogyrodactylus is a valid genus, because of the characteristic morphological differences in the features of the hamuli and the male copulatory organ (MCO) from species of Gyrodactylus. The first molecular data on Afrogyrodactylus and its phylogenetic position among Gyrodactylidae confirmed the validity of the genus (Přikrylová et al. 2013).

The present study provides a revision of Afrogyrodactylus and describes two new species of the genus from two alestid hosts from geographically distant localities in Africa.

\section{MATERIALS AND METHODS}

Gyrodactylid monogeneans were collected from the fins and gills of two alestid species, the nurse tetra, Brycinus nurse (Rüppel) and the sharptooth tetra, Micralestes acutidens (Peters) during parasitological investigations freshwater fish in three African countries between November 2004 and March 
Table 1. Summary on localities, collection period and number of studied (N)/infected (n) host fish from which Afrogyrodactylus spp. for the present study were collected.

\begin{tabular}{lccccc}
\hline Country & Locality & Host species & N/n & TL & Date of collection \\
\hline Senegal & $\begin{array}{c}\text { Niokolo Koba National Park, River Gamba } \\
\left(13^{\circ} 01.39^{\prime} \mathrm{N} ; 13^{\circ} 17.35^{\prime} \mathrm{W}\right)\end{array}$ & $\begin{array}{c}\text { Brycinus nurse } \\
\text { (Rüppell) }\end{array}$ & $19 / 2$ & $46-155$ & November 2004, March 2008 \\
Sudan & $\begin{array}{c}\text { Sennar, Blue Nile } \\
\left(13^{\circ} 32.81^{\prime} \mathrm{N} ; 33^{\circ} 38.17^{\prime} \mathrm{E}\right)\end{array}$ & $\begin{array}{c}\text { Brycinus nurse } \\
\text { (Rüppell) }\end{array}$ & $17 / 2$ & $107-127$ & January 2008, 2009 \\
South Africa & $\begin{array}{c}\text { Nwanedi Resort, Nwanedzi River } \\
\left(22^{\circ} 37.99^{\prime} \mathrm{S} ; 30^{\circ} 24.07^{\prime} \mathrm{E}\right)\end{array}$ & $\begin{array}{c}\text { Micralestes acuditens } \\
\text { (Peters) }\end{array}$ & $20 / 11$ & $51-81$ & March 2012
\end{tabular}

$\mathrm{TL}$ - total length of collected fish in millimetres.

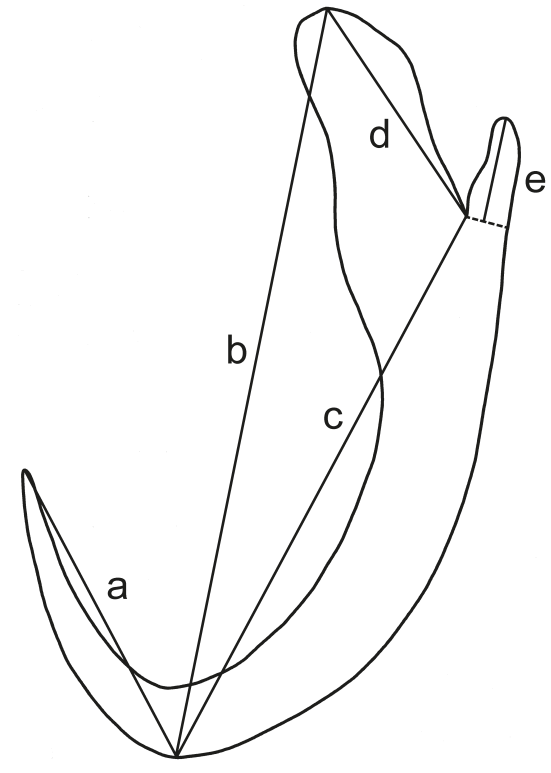

Fig. 1. Scheme of measurements of hamuli of Afrogyrodactylus spp. Abbreviations: $\mathrm{a}$ - total length; $\mathrm{b}$ - point length; $\mathrm{c}$ - shaft length; $\mathrm{d}$ - inner root length; $\mathrm{e}$ - outer root length.

2012. Fish were collected using seine nets, identified according to Skelton (2001) and kept in containers with aerated river water until examination. Details on the localities and sampling dates are provided in Table 1. Parasites were removed from the hosts' fins and gills. Their haptors were excised, fixed with ammonium picrate-glycerine (Malmberg 1970) and mounted on slides for subsequent morphological analysis. The anterior ends of the parasite bodies were stored in $99 \%$ ethanol. Specimens collected in the Sudan were directly fixed in $99 \%$ ethanol and slides were prepared in the laboratory following the procedure published by Rokicka et al. (2007).

Morphological analysis of the collected parasite specimens was performed using a phase-contrast microscope (Olympus BX51). Hard parts and body anatomy were drawn with the aid of a drawing attachment. Measurements of hamuli were taken for each specimen as shown in Fig. 1. Parameters of such as measurements of bars and size of the body and marginal hook were taken based on Christison et al. (2005). All measurements are in micrometres $(\mu \mathrm{m})$ and are presented as range with mean and number of specimens studied in parentheses.

Molecular analysis of the parasites collected in the Sudan were carried out as the part of the study whose results were published by Přikrylová et al. (2013). The DNA extraction and ITS rDNA region amplification from parasites collected in South
Africa were processed following the protocol of Přikrylová et al. (2013). The newly obtained sequences were searched in the NCBI nucleotide database using BLAST (Zhang et al. 2000) to establish possible identity with other species.

\section{RESULTS}

\section{Afrogyrodactylus Paperna, 1968}

Amended generic diagnosis. Body fusiform, comprising prohaptor and opisthaptor. Prohaptor bilobed, bearing spike sensilla; anterior adhesive gland cells lateral to pharynx. Eye spots absent. Pharynx spherical, consisting of two bulbs; pharyngeal processes not observed. Oesophagus short; bifurcated, simple blind intestinal crura which extend beyond egg cell forming region (ECFR). Male copulatory organ (MCO) situated in muscular pouch anterior to intestinal cruca, without spines and spinelets absent, exiting through a duct opening to body surface via a pore. Vesicula seminalis posterior to MCO, communicating with it via short duct; sperms visible in vesicula seminalis of several specimens. Female reproductive system dominated by thick-walled tubular uterus, usually containing F1 embryos. F2 embryos not observed. Opisthaptor clearly demarcated from trunk, with a pair of hamuli, simple ventral and dorsal bar, and 16 marginal hooks positioned along whole margin of opisthaptor. All marginal hooks bear filament loop. Hamuli with well-developed outer root, possessing small constriction where its point merges into its shaft.

\section{Afrogyrodactylus girgifae sp. $\mathrm{n}$.}

Figs. 3, 4, 10-12, 17, Table 2

\section{Syn. Afrogyrodactylus sp. of Přikrylová et al. (2013)}

Description (based on ten coverslip-flattened specimens and six excised opisthaptors of sequenced individuals): Total body length $260-396(335, \mathrm{n}=6)$; maximum body width at level of uterus 90-249 $(141, \mathrm{n}=6)$. Pharyngeal bulb $35-48(43, n=4)$ long and $30-36(33, n=4)$ wide across anterior bulb. Excretory bladders present. MCO elongate, observed for one specimen only, 20 long and 10 wide at base. Ventral bar simple, membrane and lateral processes absent. Hamuli connected with simple dorsal bar. Measurements of opisthaptoral hard parts given in Table 2. Slender hamuli, junction on inner and outer roots opens under very sharp angle. Outer roots 
Table 2. Comparison of the measurements (in $\mu \mathrm{m}$, range with mean in parentheses) of the haptoral hard parts of Afrogyrodactylus spp.

\begin{tabular}{|c|c|c|c|c|}
\hline Measurements & $\begin{array}{c}\text { A. characinis } \\
(\mathrm{n}=7) \\
\text { Paperna (1968) }\end{array}$ & $\begin{array}{l}\text { A. girgifae sp. } \mathrm{n} \text {. } \\
\qquad(\mathrm{n}=16) \\
\text { Present study }\end{array}$ & $\begin{array}{l}\text { A. kingi sp. } \mathrm{n} \text {. } \\
\quad(\mathrm{n}=13) \\
\text { Present study }\end{array}$ & $\begin{array}{l}\text { Afrogyrodactylus sp. } \\
\qquad(\mathrm{n}=2) \\
\text { Present study }\end{array}$ \\
\hline Hamulus total length & $55-70$ & $33.3-36.2(34.8)$ & $27.2-31.3(29.1)$ & $28.1-31.6$ \\
\hline Hamulus point length & - & $13.1-15.1(14.1)$ & $9.9-12.4(11.2)$ & $13.2-13.6$ \\
\hline Hamulus shaft length & - & $26.8-31.3(28.7)$ & $23.0-26.9(24.0)$ & $25.9-26.1$ \\
\hline Hamulus outer root length & $5-10$ & $4.3-6.6(5.4)$ & $5.5-5.9(5.0)$ & $4.2-4.4$ \\
\hline Hamulus inner root length & $8-11$ & $10.2-13.6(12.3)$ & $7.4-10.4(8.8)$ & $9.5-10.2$ \\
\hline Ventral bar width & - & $10.2-15.0(12.8)^{\mathrm{a}}$ & $10.0-11.5(10.8)$ & 11.9 \\
\hline Ventral bar length & $10-12$ & $4.5-6.0(5.3)^{\mathrm{a}}$ & $4.3-6.2(5.3)$ & 4.2 \\
\hline Dorsal bar width & $10-12$ & $10.4-10.8(10.6)^{\mathrm{d}}$ & $8.4-9.9(9.1)^{\mathrm{c}}$ & - \\
\hline Dorsal bar length & - & $1.0-1.3(1.1)^{\mathrm{d}}$ & $1.0-1.2(1.1)^{\mathrm{c}}$ & - \\
\hline Marginal hook total length & $20-30$ & $19.0-21.9(20.9)^{\mathrm{b}}$ & $18.4-20.0(19.1)$ & 18.7 \\
\hline Marginal hook sickle length & $5-7$ & $3.2-3.7(3.5)^{\mathrm{b}}$ & $3.2-3.6(3.4)$ & 3.1 \\
\hline Marginal hook handle length & - & $15.4-18.3(17.4)^{\mathrm{b}}$ & $15.1-16.4(15.4)$ & 15.7 \\
\hline Marginal hook distal width & - & $2.4-2.9(2.6)^{\mathrm{b}}$ & $2.2-2.9(2.5)$ & 2.3 \\
\hline Marginal hook proximal width & - & $2.8-3.7(3.3)^{\mathrm{b}}$ & $2.9-3.4(3.1)$ & 3.3 \\
\hline Marginal hook aperture distance & - & $2.7-3.2(2.9)^{\mathrm{b}}$ & $2.6-3.0(2.8)$ & 2.6 \\
\hline
\end{tabular}

Number of measured specimens: $\mathrm{a}-12 ; \mathrm{b}-9 ; \mathrm{c}-6 ; \mathrm{d}-2$.

maximum half of length of inner roots (Fig. 3). Robust shaft of marginal hook sickle rises forward from base and curves gradually (Figs. 4, 11, 12). Point of marginal hook sickle ends above edge of toe. Foot with heel of rounded edge. Pronounced sickle toe, leading edge partly flattened on upper surface, then slanting down to toe.

Type host: Nurse tetra, Brycinus nurse (Rüppell) (Characiformes: Alestidae).

Site of infection: Fins.

Type 1 oc a lity: Sennar, Blue Nile $\left(13^{\circ} 32.81^{\prime} N ; 33^{\circ} 38.17^{\prime} E\right)$, Sudan.

Type specimens: Holotype and two paratypes deposited in the Institute of Parasitology, Biology Centre of the Academy of Sciences of the Czech Republic in České Budějovice, Czech Republic (IPCAS; Coll. No. M-554), three paratype specimens, the Natural History Museum London, UK (NHMUK 2014.7.16.4-6).

Etymology: The specific name is derived from 'girgifa', common name for $B$. nurse in Nubian, old Sudanese language.

Sequence data: For molecular characterisation, a 713 bp fragment covering ITS1 (312 bp), 5.8S (157 bp) and ITS2 (244 bp) was successfully sequenced from three specimens and submitted to GenBank under accession number HF548671. The entire sequence was identical for the three specimens. A BlastN (Zhang 2000) search in GenBank March 2012 using the entire sequence revealed no identical or close hits.

Remarks. Overall dimensions of hamuli and sickle of marginal hooks of $A$. girgifae sp. n. differ significantly from those of $A$. characinis provided in the original description (Paperna 1968; see Table 2). Moreover, dimensions of $A$. girgifae sp. n. differ from those of $A$. kingi sp. n. and Afrogyrodactylus sp. found in the present study (Table 2). There is only one overlap in the dimension of hamulus point length of $A$. girgifae and Afrogyrodactylus sp. (13.1-15.1 $\mu \mathrm{m} v s$ 13.2-13.6 $\mu \mathrm{m})$. Both species differ substantially in the shape of marginal hook sickles. The shaft of marginal hook sickles of $A$. girgifae starts slanted forward, is regularly curved and more slender than that of Afrogyrodactylus sp., which has a more sturdy sickle proper rising perpendicular to the foot.

\section{Afrogyrodactylus kingi sp. n.}

Figs. 5, 6, 13, 14, 18, Table 2,

Description (based on 11 coverslip-flattened specimens and two excised opisthaptors of sequenced individuals): Total body length 497-784 (649, $\mathrm{n}=11)$; maximum body width at level of uterus $62-135(110, \mathrm{n}=11)$. Pharyngeal bulb $32-48(40, \mathrm{n}=11)$ long, 30-44 $(38, \mathrm{n}=11)$ wide across anterior bulb. Excretory bladders present. MCO elongate, observed for two specimens, 17.7-22.2 long and 5.1-5.6 wide at base. Ventral bar simple, membrane and lateral processes absent. Hamuli connected with a simple dorsal bar. Measurements of opisthaptoral hard parts given in Table 2. Slender hamuli, broadening at junction of inner and outer roots. Conspicuous outer roots more than half length of inner roots (Fig. 5). Shaft of marginal hook sickle rises mildly forward, turns sharply downward towards toe (Figs. 6, 13, 14). Point of marginal hook sickle ends above edge of toe. Sickle proper with a broad foot. Well-developed heel with rounded edge lies posterior to bottom edge of toe. Upper edge of short toe extends straight forward and then slants to tip.

Type host: Sharptooth tetra, Micralestes acuditens (Peters) (Characiformes: Alestidae).

Site of infection: Gills.

Type locality: Nwanedi Resort, Nwanedzi River $\left(22^{\circ} 37.99^{\prime} \mathrm{S} ; 30^{\circ} 24.07^{\prime} \mathrm{E}\right)$, South Africa.

Type specimens: Holotype and two paratypes (IPCAS M-553), three paratypes (NHMUK 2014.7.16.1-3). 

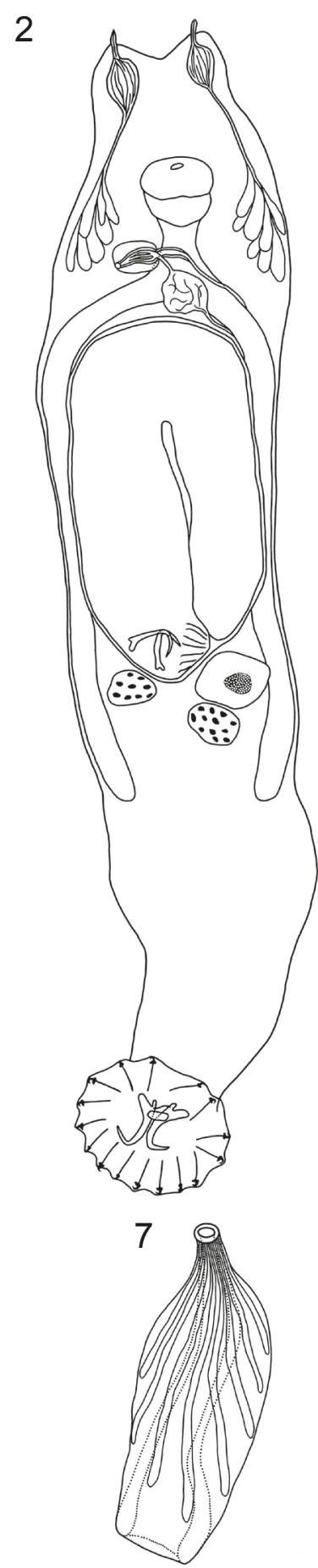
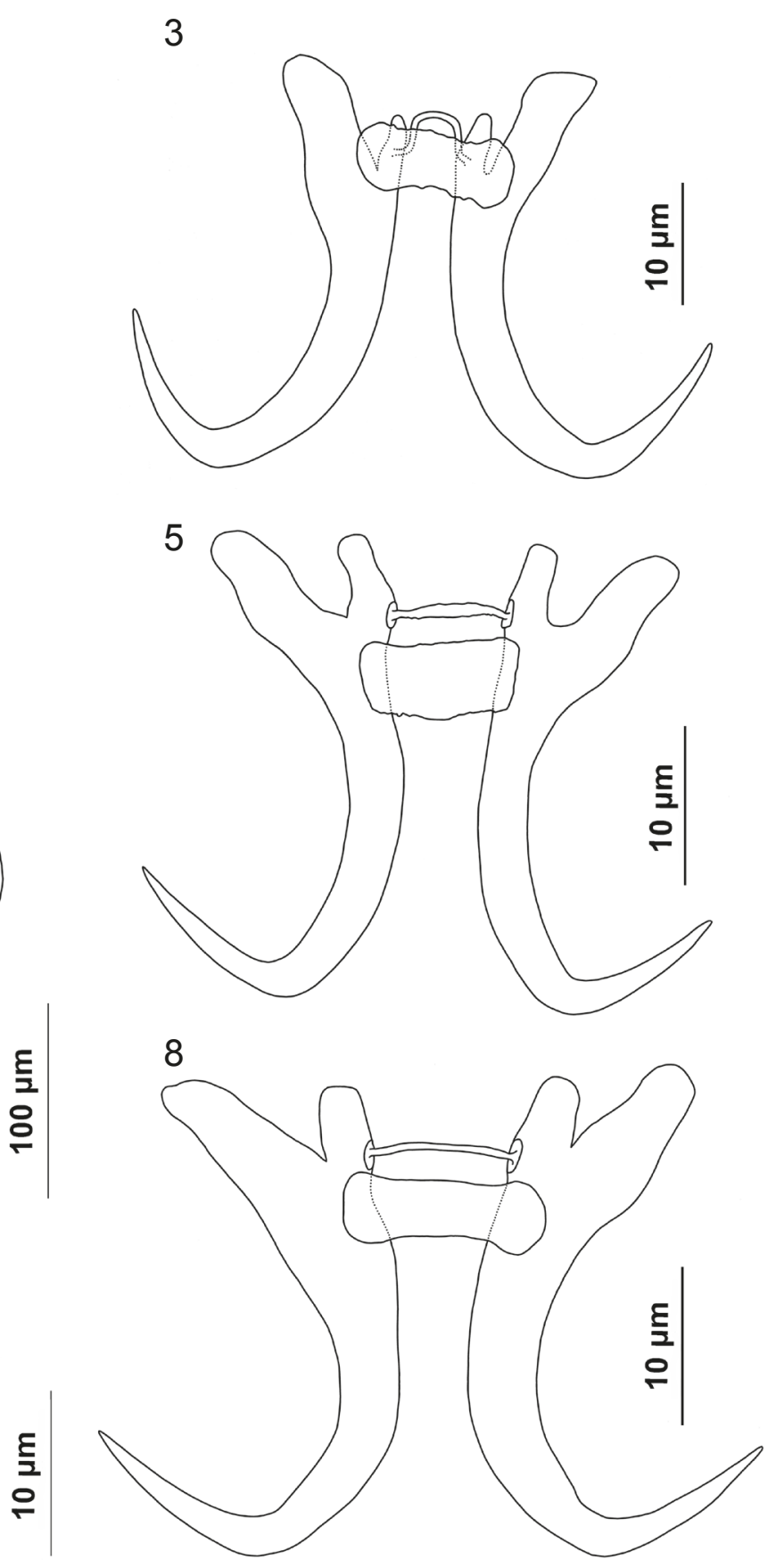

4

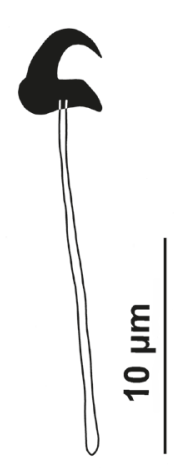

6

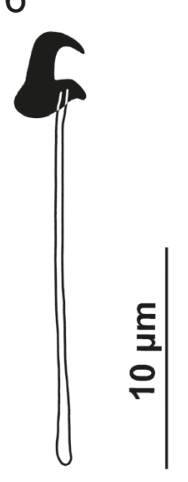

9

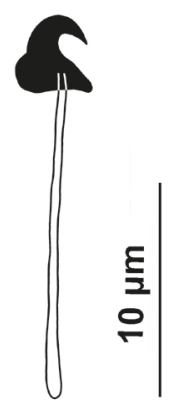

Figs. 2, 7-9. Afrogyrodactylus sp. from Brycinus nurse, Senegal (voucher specimens M-555). Figs. 3, 4. Afrogyrodactylus girgifae sp. n. from Brycinus nurse, Sudan (holotype M-554). Figs. 5, 6. Afrogyrodactylus kingi sp. n. from Micratestes acuditens, South Africa (holotype M-553). Fig. 2. Composite drawing. Figs. 3, 5, 8. Hamuli. Figs. 4, 6, 9. Marginal hook. Fig. 7. Male copulatory organ.

Etymology: The specific name honours Piet H. King from the Department of Biology, Faculty of Health Sciences, University of Limpopo, recognising his particular contribution during the field work.

Sequence data: For molecular characterisation, a 639 bp fragment covering ITS1 (270 bp), 5.8S (157 bp) and ITS2 (212 bp) was successfully sequenced from two specimens and submitted to GenBank under accession number HG970104. The entire sequence was identical for both specimens.

Remarks. Based on the dimensions of hamuli, $A$. kingi sp. n. resembles Afrogyrodactylus sp. found in the present study (see Table 2) but these two species differ in hamulus point length (9.9-12.4 vs 13.2-13.6 $\mu \mathrm{m})$ and hamulus 

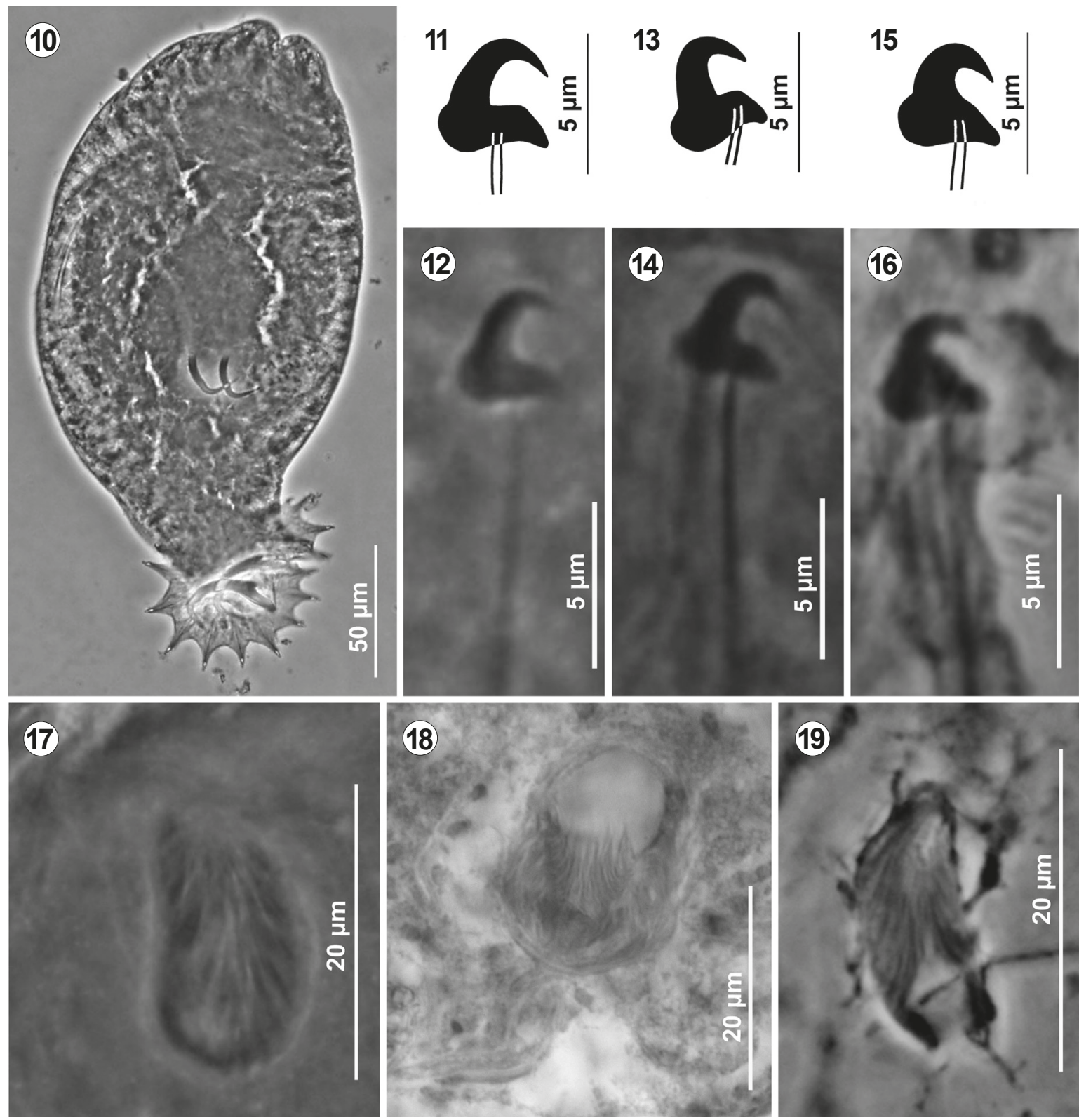

Figs. 10-12, 17. Afrogyrodactylus girgifae sp. n. from Brycinus nurse, Sudan. Figs. 13, 14, 18. Afrogyrodactylus kingi $\mathrm{sp.}$. from Micratestes acuditens, South Africa. Figs. 15, 16, 19. Afrogyrodactylus sp. from Brycinus nurse, Senegal. Fig. 10. Total view, wholemounted specimen. Fig. 11-16. Marginal hooks. Figs. 17-19. Male copulatory organ.

outer root length (5.5-5.9 vs 4.2-4.4 $\mu \mathrm{m})$. Differences in the shape of marginal hook sickles can be also observed (Figs. 6, 9, 13, 14, 15, 16). The foot of the sickle of $A$. kingi is slanted with a short toe, the proper sickle rising slightly forward with rouding in the terminal part. In contrast, the foot has a bigger body and lower line in the horizontal plane, in Afrogyrodactylus sp. and sturdy proper sickle turns immediately after rising from the foot.

A BlastN (Zhang 2000) search in GenBank on 11 March 2013 using the entire sequence revealed only one close hit, i.e. Afrogyrodactylus sp. (Genbank Acc. No. HF548671) deposited by Přikrylová et al. (2013), the species that is described as $A$. girgifae sp. n. in the present study. Alto- gether, there are 76 differences between the ITS sequences of $A$. kingi sp. n. and $A$. girgifae sp. n. These substitutions can be attributed to 40 in ITS 1 ( 21 transitions and 19 transversions), five substitutions in 5.8S (3 transitions and 2 transversions) and 31 substitutions in ITS2 (17 transitions and 14 transversions). In addition, seven indels were found, five and two in ITS1 and ITS2, respectively. The large number of differences (76 out of 639) observed in the ITS regions suggests that these are different species.

Afrogyrodactylus sp.

Figs. 8, 9, 15, 16, 19, Table 2

Description (based on two coverslip-flattened specimens): Total body length 500-505; maximum body width 
at level of uterus 90-107. Pharyngeal bulb 44-45 long, 36-43 wide across anterior bulb. Excretory bladders present. MCO elongate, 15-17 long and 5-6 wide at base. Ventral bar simple, membrane and lateral processes absent. Hamuli connected with simple dorsal bar. Measurements of opisthaptoral hard parts given in Table 2. Hamuli of more sturdy appearance, well developed outer roots at maximum half length of inner roots. Junction between inner and outer roots moderately open, hamuli noticeably broaden in this part. Hamuli with small constriction where point merges into its shaft (Fig. 8). Marginal hook sickle robust, short sturdy shaft of marginal hook sickle rises upright, immediately turns round into short point nor crossing beyond edge of toe (Figs. 9, 15, 16). Rounded heel extends slightly backward. Triangular toe smoothly merges into shaft of marginal hook sickle.

H o s t: Nurse tetra, Brycinus nurse (Rüppell) (Characiformes: Alestidae).

Site of infection: Fins.

Locality: Post Simenti, Gambia River $\left(13^{\circ} 01.39^{\prime} \mathrm{N}\right.$; $\left.13^{\circ} 17.35^{\prime} \mathrm{W}\right)$, Senegal.

Specimens deposited: Two specimens (IPCAS M-555).

Remarks. Due to the limited number of studied specimens, the formal description of this unknown species is not presented here. The size of the haptoral hard parts is considerably smaller than those of $A$. characinis, but similar in size to that of $A$. kingi sp. n. (Table 2). However, the shape of the marginal hook sickle and hamuli differ between Afrogyrodactylus sp. and A. kingi sp. n. Moreover Afrogyrodactylus sp. has more robust hamuli than $A$. girgifae sp. n. and $A$. kingi sp. n.

\section{DISCUSSION}

The genus Afrogyrodactylus differs from other gyrodactylid genera in a number of characteristics. These include the hamuli with well-developed outer root and the $\mathrm{MCO}$, which differs from the bulbous Gyrodactylus-type by having an elongated muscular pouch with no spines or spinelets. Within the Gyrodactylidae, based on the morphology of opisthaptoral hard parts (the hamuli with a well-formed outer root), Afrogyrodactylus is most similar to the genera Archigyrodactylus Mizelle et Kritsky, 1967, Gyrdicotylus, Gyrodactyloides Bychowsky, 1947 and Laminiscus Palsson et Beverly Burton, 1983. Archigyrodactylus, Laminiscus and Gyrodactyloides are marine parasites with additional plates on their opisthaptors or with ventral bar membrane extended into wings that spread back around the opisthaptor to the hamulus roots.

In contrast, Gyrdicotylus specimens have the opisthaptor modified into two suckers and parasitise amphibian hosts. Until the bulbous MCO with spines varying in numbers and size as recorded for Gyrodactylus spp. (Malmberg 1970) and some other gyrodactylid genera
(Malmberg 1957, Kritsky and Thatcher, 1977), Afrogyrodactylus has a partially elongated muscular MCO inside which the internal duct can be observed and which extends and opens at the body surface via a pore (Figs. 17, 19). When fully developed, the MCO can widely open, as observed for one specimen of $A$. kingi (Fig. 18). Nevertheless, the muscular character of the MCO suggests that the twisting and contracting of the pouch is a possible means by which the sperm can reach the parasite's body surface. A similar muscular type of MCO has been previously described for Diplogyrodactylus (see Přrikrylová et al. 2009), but its function has not been discussed.

Among viviparous gyrodactylids, the internal duct extending through the $\mathrm{MCO}$ is probably not limited to Afrogyrodactylus, as similar structures of this nature have been observed for another not described yet gyrodactylid genus, but in this case the parasite has outer spinous reinforcement of the MCO (personal observation). Some egg-laiyng genera, such as Ooegyrodactylus Harris, 1983, have an entirely muscular MCO or the duct may be unarmed or armed with spines or rods as in Phanerothecioides Kritsky, Vianna et Boeger, 2007. Paperna (1968) described the MCO for A. characinis as being a muscular pouch with an inner wall inserted with minute rods or spines. Our observations of specimens of three other species of Afrogyrodactylus under polarised light did not confirm any such sclerotised elements of the pouch.

The body of Afrogyrodactylus spp. has a long peduncle but the internal structure in this part of the body is difficult to observe. Generally, few details (the egg cell forming region or the testis) have been observed, although sperm were observed in the vesicula seminalis. Unfortunately, the original description of $A$. characinuis does not provide detailed information on the internal anatomy and the drawing of the parasite body provided by Paperna (1968) shows few internal structures, which makes it difficult to confirm whether this species is progenetic or not (Harris 1983, Bakke et al. 2007).

The shape of marginal hook sickles is a crucial characteristic feature used for species identification among the viviparous gyrodactylid genera (Malmberg 1970, Shinn et al. 2001, Paladini et al. 2010, Přikrylová et al. 2012). From our observations, it seems that the morphology of the marginal hook sickles is a very important feature for the identification of Afrogyrodactylus species as well. Drawings and photomicrographs from detailed morphological analysis show the differences in the shape of marginal hook sickles of studied species (see Figs. 4, 7, 9, 11-16). Because of the similarity in hamulus dimensions in all the species examined, the shape of marginal hook sickles is crucial for species differentiation in Afrogyrodactylus. No comparison with the type material of A. characinis was possible because no information could be found pertaining to the original description or type material, possibly because of the destruction of many of 
Paperna's type specimens in a fire (A.P. Shinn, Fish Vet Group Asia Limited, Bangkok, Thailand - pers. comm.). Measurements of three identified species differ distinctly from those reported by Paperna (1968) for A. characinis (Table 2), which indicates that the present study has yielded three distinguishable species of Afrogyrodactylus.

Results of the phylogenetic analysis of African gyrodactylids (Přikrylová et al. 2013), make it clear that Afrogyrodactylus is a distinct genus, unrelated to Gyrodactylus. Although Afrogyrodactylus clustered with Gyrodactylus sp. 3 of Přikrylová et al. (2013), but this was due to the fact that Gyrodactylus sp. 3 was atypical and may represent a distinct and as yet undescribed genus. This assumption is supported by a description of the morphological similarities and differences between Afrogyrodactylus and that of an undescribed genus, and it is also highly supported by observed genetic distances between them in both ITS and 18S rDNA regions, $31.2 \%$ and $6.4 \%$, respectively (Přikrylová et al. 2013).

Five different sites (3.2\%) within the conservative 5.8S molecule of rDNA between two Afrogyrodactylus species show that newly identified species are not very closely related. Among the genus Gyrodactylus, level of variation up to $6.4 \%$ within the $5.8 \mathrm{~S}$ rDNA region was noted (Ziętara et al. 2002), which is more than intrageneric differences reported for tropical Cnidaria (up to $2.6 \%$ ) and even higher than the variation found between nematode families and superfamilies (up to 5.2\%) (Chen et al. 1996, Chilton et al. 1997, Zhu et al. 1998).

However, $5.8 \mathrm{~S}$ can be very conserved within the natural taxonomic groups in Gyrodactylus as in the G. wageneri- group or closely related African species (Ziętara and Lumme 2003, García-Vásquez et al. 2011, Přikrylová et al. 2012). Such level of variation is remarkable and is probably a consequence of extreme morphological conservatism due to pedogenetic polyembryony in the group. Together, the role of the geographical isolation and the host diversification can not be overlooked. Arroyave and Stiassny (2011) estimated divergence between lineages of Brycinus Valenciennes and those including Micralestes Boulenger around 45 mya, providing a sufficiently long period to contribute for such changes to occur.

We believe that Afrogyrodactylus might be a more diverse genus than it is currently known today. The small size of both the hosts and parasites might be the reason why these parasites are often overlooked.

Acknowledgements. We are grateful to Radim Blažek for collection of material in the Sudan. I.P. received financial support of the Czech Sciences Foundation (projects Nos. P505/11/P470 and P505/12/G112). Department of Botany and Zooology, Faculty of Science, Masaryk University is gratefully acknowledged for hosting the morphological and molecular processing of the analysed material. The research done in South Africa was funded by the University of Limpopo and the National Research Foundation (Thuthuka Programme; TTK2006062100013). Any opinion, findings and conclusions or recommendations expressed in this material are those of the authors and therefore the NRF does not accept any liability in this regard. Piet King and Hendrik Hattingh are thanked for their valuable assistance with fieldwork.

\section{REFERENCES}

Arroyave J., Stiassny M.L.J., 2011: Phylogenetic relationships and the temporal context for the diversification of African characins of the family Alestidae (Ostariophysi: Characiformes): Evidence from DNA sequences data. Mol. Phylogenet. Evol. 60: 385-397.

Bakke T.A., Cable J., Harris P.D. 2007: The biology of gyrodactylid monogeneans: the "Russian-doll killers." Adv. Parasit. 64: 161-276.

Birgi E. 1988: Les monogènes de Characoidea de la zone forestiere Camerouniase. Ann. Fac. Sci. Biol. Bioch. 111: 59-111.

Chen C.A., Wills B.L., Miller D.J. 1996: Systematic relationships between tropical corallimorpharians (Cnidaria: Anthozoa: Corallimorpharia): utility of the 5.8S and internal transcribed spacer (ITS) regions of the rRNA transcription unit. Bull. Mar. Sci. 59: 196-208.

Chilton N.B., Gasser R.B., Beveridge I. 1997: Phylogenetic relationship of Australian strongyloid nematodes inferred from ribosomal DNA sequence data. Int. J. Parasitol. 27: 1481-1494.

Christison K.W., Shinn A.P., van As J.G. 2005: Gyrodactylus thlapi sp. n. (Monogenea) from Pseudocrenilabrus philander philender (Weber) (Cichlidae) in the Okawango Delta, Botswana. Syst. Parasitol. 60: 165-173.
ERGENS R. 1973: Characitotrema nursei n. sp. from the gills of Alestes nurse from River Nile (Vermes, Trematoda; Monogenoidea). Rev. Zool. Bot. Africaines 87: 195-197.

García-Vásquez A., Hansen H., Christison K.W., Bron J.E., Shinn A.P. 2011: Description of three new species of Gyrodactylus von Nordmann, 1832 (Monogenea) parasitising Oreochromis niloticus niloticus (L.) and O. mossambicus (Peters) (Cichlidae). Acta Parasitol. 56: 20-33.

HARRIS P.D. 1983: The morphology and life-cycle of the oviparous Oogyrodatylus farlowellae gen. et sp. nov. (Monogenea, Gyrodactylidea). Parasitology 87: 405-420.

Kritsky D.C., Thatcher V.E. 1977: Phanerothecium gen. nov. and Fundulotrema gen. nov. two new genera of viviparous Monogenea (Gyrodactylidea) with a description of P. caballeroi sp. nov. and a key to the subfamilies and genera of the family. Excerta Parasitologica in Memoria del doctor Eduardo Caballero y Caballero. Instituto de Biología, Univesidad National Antónom de México, México, D.F. Publicaciones Especiales 4: 53-60.

MalmberG G. 1957: On the new genus of viviparous monogenetic trematodes. Ark. Zool. 2: 317-329.

Malmberg G. 1970: The excretory systems and marginal hooks as basis for the systematics of Gyrodactylus (Trematoda, Monogenea). Ark. Zool. 2: 1-235. 
Molnár K., Mossalam I. 1985: Monogenean parasites from fishes of the Nile, Egypt. Parasitol. Hung. 18: 5-9.

Nelson J.S. 2006: Fishes of the World. 4th Edition. John Wiley and Sons, Inc., New York, 601 pp.

Paladini G., Cable J., Fioravanti M.L., Faria P.J., Shinn A.P. 2010: The description of Gyrodactylus corleonis sp. n. and G. neretum sp. n. (Platyhelminthes: Monogenea) with comments on other gyrodactylids parasitising pipefish (Pisces: Syngnathidae). Folia Parasitol. 57: 17-30.

Paperna I. 1968: Monogenetic trematodes collected from freshwater fish in Ghana. Bamidgeh 20: 88-99.

Paperna I. 1969: Monogenetic trematodes of fish of the Volta basin and south Ghana. Bull. Inst. Fondam. Afr. Noir 31: 840-880.

PAPERNA I. 1973: New species of Monogenea (Vermes) from African freshwater fish. A preliminary report. Rev. Zool. Bot. Afr. 87: $505-518$

Paperna I. 1979: Monogenea of inland water fish in Africa. Ann. Mus. Roy. Afr. Centr., Sci. Zool., Ser. 8, 226, 131 pp.

Přikrylová I., Blažek R., Vanhove M.P.M. 2012: An overview of the Gyrodactylus (Monogenea: Gyrodactylidae) species parasitizing African catfishes, and their morphological and molecular diversity. Parasitol. Res. 110: 1185-1200.

PŘikrylová I., Matějusová I., Musilová N., Gelnar M., HARR IS P.D. 2009: A new gyrodactylid (Monogenea) genus on gray bichir, Polypterus senegalus (Polypteridae) from Senegal (West Africa). J. Parasitol. 95: 555-560.

Přikrylová I., Vanhove M.P.M., Janssens S.B., Bileter P.A., Huyse T. 2013: Tiny worms from a mighty continent: high diversity and new phylogenetic lineages. Mol. Phylogenet. Evol. 67: 43-52.

Rokicka M., Lumme J., ZiĘtara M. 2007: Identification of Gyrodactylus ectoparasites in Polish salmonid farms by PCR-
RFLP of the nuclear ITS segment of ribosomal DNA (Monogenea, Gyrodactylidae). Acta Parasitol. 52: 185-195.

Shinn A.P., Gibson D.I., Sommerville C. 2001: Morphometric discrimination of Gyrodactylus salaris Malmberg (Monogenea) from species of Gyrodactylus parasitising British salmonids using novel paramaters. J. Fish Dis. 24: 83-97.

Skelton P.H. 2001: A complete Guide to the Freshwater Fishes of Southern Africa. Struik Publishers, Cape Town, South Africa. $395 \mathrm{pp}$.

Thomas J.D. 1957: A new monogenetic trematode, Diplozoon ghanense sp. nov. (Polyopisthocotylea: Discocotylea), from a West African fish Alestes macrolepidotus (C \& V, 1849) in West Africa. J. West Afric. Sci. Assoc. 3: 178-182.

Thurston J.P. 1970: The incidence of Monogenea and parasitic Crustacea on the gills of fish in Uganda. Rev. Zool. Bot. Afr. 82: $111-130$.

Vercammen Grandjean P. H. 1960: Les trematodes du lac Kivu Sud (Vermes). Ann. Mus. Roy. Afr. Centr. Scien. Zool. 5: 1-171.

Ziętara M., Huyse T., Lumme J., Volckaert F.A. 2002: Deep divergence among subgenera of Gyrodactylus inferred from rDNA ITS region. Parasitology 124: 39-52.

Ziętara M., Lumme J. 2003: The crossroads of molecular, typological and biological species concepts: two new species of Gyrodactylus Nordmann, 1832 (Monogena: Gyrodactylidae). Syst. Parasitol. 55: 39-52.

Zhang Z., Schwarts S., Wagner L., Miller W. 2000: A greedy algorithm for aligning DNA sequences. J. Comput. Biol. 7: 203-214.

Zhu X.Q., Gasser R.B., Chilton N.B. 1998: Differences in the 5.8S $\mathrm{r}$ DNA sequences of ascarid nematodes. Int. J. Parasitol. 28: 617-622. 